\title{
INFLUENCE OF D-ASPARAGINE ON THE ENGRAFTMENT OF A BIOPOLYMER SCAFFOLD FOR REPLACING SKIN DEFECTS
}

\author{
Kade A. Kh. ${ }^{1}$, Trofimenko A. I. ${ }^{1,}{ }^{2}$, Bogdanov S. B. ${ }^{1,}{ }^{2}$, Galushko Yu. V. ${ }^{1}$, Zench S. M. ${ }^{1}$ \\ ${ }^{1}$ Kuban State Medical University, Krasnodar, Russian Federation \\ 2 Scientific-Research Institute - Regional Clinical Hospital № 1, Krasnodar, \\ Russian Federation
}

\section{ВАИЯНИЕ D-АСПАРАГИНА НА ПРИЖИВАЕНИЕ БИОПОАИМЕРНОГО СКАФФОААА ПРИ ЗАМЕЩЕНИИ АЕФЕКТОВ КОЖИ}

\author{
А. Х. КаАе 1, А. И. Трофименко 1, 2, С. Б. БогАанов 1, 2, Ю. В. Галушко ', С. М. Зенч ${ }^{1}$ \\ 1 Кубанский госуАарственный меАицинский университет, КрасноАар, \\ Российская ФеАерация \\ 2 Научно-исслеАовательский институт - Краевая кАиническая больница № 1 \\ им. профессора С. В. Очаповского, Краснодар, Российская ФеАерация
}

\begin{abstract}
The influence of D-asparagine on the engraftment of a biopolymer scaffold, the main components of which were sodium alginate and gelatin, for replacing skin defects after necrectomy of burn wounds was investigated in an experimental rat model. The results of morphometric and fractal analyses of histological micro-preparations showed that the inclusion of D-asparagine in the composition of the scaffold had a positive effect on its engraftment and remodeling on day 30 after implantation. The study showed that the proposed scaffold is a promising material for replacing the skin in burn wounds.
\end{abstract}

Keywords: D-asparagine, biopolymer scaffold, skin, burn, fractal analysis

Изучено влияние D-аспарагина на приживление биополимерного скаффолда для замещения дефектов кожи после некрэктомии ожоговых ран в эксперименте у крыс. По результатам морфометрического и фрактального анализа гистологических микропрепаратов показано, что включение D-аспарагина в состав скаффолда, основными компонентами которого являются альгинат натрия и желатин, оказывает положительное влияние на его приживление и ремоделирование на 30-е сутки после имплантации.

Ключевые слова: D-аспарагин, биополимерный скаффолд, кожа, ожог, фрактальный анализ

For citation: Kade A. Kh., Trofimenko A. I., Bogdanov S. B., Galushko Yu. V., Zench S. M. INFLUENCE OF D-ASPARAGINE ON THE ENGRAFTMENT OF A BIOPOLYMER SCAFFOLD FOR REPLACING SKIN DEFECTS. Medical News of North Caucasus. 2021;16(2):184-187. DOI - https://doi.org/10.14300/mnnc.2021.16042

Для цитирования: Каде А. Х., Трофименко А. И., Богданов С. Б., Галушко Ю. В., Зенч С. М. ВЛИЯНИЕ D-АСПАРАГИНА НА ПРИЖИВЛЕНИЕ БИОПОЛИМЕРНОГО СКАФФОЛДА ПРИ ЗАМЕЩЕНИИ ДЕФЕКТОВ КОЖИ. МЕДИцинский вестник Северного Кавказа. 2021;16(2):184-187. DOI - https://doi.org/10.14300/mnnc.2021.16042

$\square$ arly necrectomy with skin autograft primary autoplasty is the method of choice in the treatment of burn injury patients [1, 2]. However, questions remain regarding the quality of skin healing, the formation of dermal scars, and the lack of donor material in patients with extensive grade III burns [1, 3]. In this regard, the development of biodegradable hydrogel scaffolds (based on biopolymers of natural origin, such as sodium alginate and gelatin) capable of performing the role of wound coating and regenerative matrix is an actual and promising approach in solving of these problems $[4,5]$.

Under experimental conditions, there is significant potential for influencing the dynamics of cellular reactions, the nature of colonization, and remodeling of the scaffold after its implantation by using modulators of the proliferative activity of dermal matrix cells, including those based on a natural metabolite such as D-asparagine [68], which expands the possibilities for studying it in burn injury models.

The aim of the study was to determine the effect of $D$-asparagine on the engraftment of a biopolymer scaffold in the replacement of skin defects after burn wounds necrectomy in rats.

Material and Methods. Twenty inbred male Wistar rats weighing 270-300 g were used in this study. All interventions capable of causing pain or suffering to animals were performed under anesthesia using $20 \mathrm{mg} /$ $\mathrm{kg}$ tiletamine hydrochloride (Zoetis Inc., USA) and $6 \mathrm{mg} /$ kg xylazine hydrochloride (NITA-PHARM, Russia), both applied intramuscularly. When performing traumatic manipulations with an antimicrobial purpose, animals were injected with $2.5 \mathrm{mg} / \mathrm{kg}$ gentamicin sulfate (Agrofarm, Russia) intramuscularly. 
Modeling of skin burns was performed according to the method of Cai et al. [9], by lowering a heating element with a contact surface area of $1 \mathrm{~cm}^{2}$, a working zone temperature of $100^{\circ} \mathrm{C}$, and a contact time of 20 seconds on the shaved surface of the skin. The temperature of the contact surface was controlled using a thermocouple. Under these conditions, damage to all layers of the skin was achieved, which corresponds to a grade IIIB burn.

One day after the burn, animals were randomized to two groups each with 10 rats: $\mathrm{N} 1$ (comparison group) with simultaneous implantation after scaffold necrectomy without D-asparagine; N2 (experimental) with simultaneous implantation after scaffold necrectomy with D-asparagine. Wound closure after scaffold implantation was performed using a self-adhesive sterile Cosmopor $\mathrm{E}$ dressing and sewn to the edges of the wound.

The hydrogel was prepared under aseptic conditions, based on the following components: sodium alginate $2.6 \mathrm{~g}$; gelatin type $\mathrm{A}-0.2 \mathrm{~g}$; D-asparagine (only in N2) $0.013 \mathrm{~g}$, vinyltriethoxysilane $-0.07 \mathrm{~g}$; DMEM/F-12 culture medium powder (without L-glutamine, L-leucine, L-lysine, L-methionine, calcium, magnesium chloride, magnesium sulfate, or phenolic red) $-1.48 \mathrm{~g}$, and the rest highly purified water up to $100 \mathrm{ml}$ per mixture. The resulting liquid was poured into Petri dishes to form a 3-mm layer and cooled to $+4{ }^{\circ} \mathrm{C}$. To polymerize the mixture, $10 \mathrm{ml}$ of a solution containing $3 \%$ aqueous hydrogen peroxide and 0.1 $\mathrm{g}$ calcium gluconate powder was carefully layered on top of the cooled mixture. The resulting mixture was frozen at $-25^{\circ} \mathrm{C}$, and after defrosting and washing, the scaffold was ready for use.

On day 30 after implantation, a skin area of $15 \times 15 \mathrm{~mm}^{2}$ was taken, including the border of the scaffold area with intact tissue. The biomaterial was subjected to fixation in a zinc-formalin fixator with zinc sulfate, followed by embedding in paraffin using isopropanol and mineral oil. Histological staining of micro-preparations obtained from paraffin blocks with a thickness of $4 \mu \mathrm{m}$ was performed according to the protocol for hematoxylin-eosin, as well as according to Mallory-Slinchenko.

Microscopy was performed using a Micmed-5 microscope (Lomo, Russia) and images were obtained using a Levenhuk M300 Base ocular camera (Levenhuk, Tampa, FL, USA). Morphometric analysis of images was performed using the program «Image J1.51j8» (NIH, USA).

For fractal analysis of the fibrillar structure of the extracellular matrix, images were converted to binary form, skeletonized, and evaluated using the FracLac 2.5 plugin (NIH) for «Image J1.51j8». The «box-counting method» was used to determine the value of the fractal dimension and lacunarity [10].

Statistical processing was performed using the program «Statistica13» (StatSoft Inc., USA). When using the ShapiroWilk test, an alternative hypothesis was adopted about the deviation from the normal distribution of features in the studied groups, and, therefore, nonparametric statistics were used. The results of the descriptive part of the analysis are presented using the median (Me) and interquartile range (Q1-Q3). Binary data were described with absolute values and percentages. To analyze the conjugacy tables of nominal features, the Fisher's exact test was applied. The Mann-Whitney test was used to assess the intergroup differences between the two independent groups. In all cases, at $p<0.05$, the null hypothesis of the absence of intergroup differences was rejected.

Results and Discussion. Visual assessment of wound defect healing showed in the experimental group that the epithelialization completion time was 21.5 (19-23) days, which was $7.5 \%$ longer than in the comparison group of $20(18.5-21)$ days $(p=0.80)$. This trend may be due to a degree of slowdown in the proliferative activity of cells under the influence of $D$-asparagine during the initial period after scaffold implantation. This hypothesis is supported by the fact that in vitro D-asparagine reduced the proliferative activity of dermal fibroblasts during a 48-hour incubation [6].

Morphological analysis of skin micro-preparations indicated the completion of the formation of a continuous layer of the epidermis by day 30 after scaffold implantation in both groups (Fig. A, B). At this time, in group N1, the epidermis was thinner with a rough disorganization of its layers, an indistinct border of the transition of the epidermis to the dermis, and the absence of dermal papillae. The papillary and reticular layers of the dermis were practically undifferentiated, while in the area of the basal and spiny epidermal layers, diffuse spongiosis and intracellular edema of cells with the formation of many small subepidermal blisters were observed. In the dermis, there were pronounced signs of inflammatory infiltration with numerous giant and epithelioid cells and a large number of large, variable-diameter vessels (Fig. A). It was important that the micro-preparations clearly traced the cellular structure of the scaffold in all the studied areas, which is typical for the implantation of «cell-free» alginategelatin scaffolds [4].

In the experimental N2 group, the thickness of the epidermis by the end of the experiment of $11(10-15) \mu \mathrm{m}$ was $45.5 \%$ greater than in the comparison group of 6 (57.8) $\mu \mathrm{m}(p=0.002)$. The differentiation of the epidermis into basal, spiny, and granular layers was observed in the micro-preparations of the N2 animals. In the basal and spiny layers, moderate focal spongiosis with small subepidermal blisters (possibly scaffold cells) was detected (Fig. B). In contrast to the comparison group, in the experimental group, the transition of the epidermis to the dermis was clearly traced, single dermal papillae were visualized (the cellular structure of the scaffold was visible), single giant and epithelioid cells were identified, and a moderate number of large, thin-walled vessels was observed, while there was no division into papillary or reticular layers of the dermis.

In the central zone at the site of the wound defect in all experimental animals, no hair follicles or sebaceous glands were detected. Single sebaceous glands and hair follicles were detected only on the periphery of the scaffold (Fig. C, D). In the N2 group, hair follicles were detected on $80 \%$ of micro-preparations compared with $30 \%$ in the comparison group $(p=0.037)$. Sebaceous glands were detected on $80 \%$ and $10 \%$ of micro-preparations of the $\mathrm{N} 2$ and $\mathrm{N} 1$ groups, respectively $(\mathrm{p}=0.002)$.

Detailed study of micro-preparations of groups $\mathrm{N} 1$ (Fig. D) and N2 (Fig. E) revealed a tendency to remodel the structure of the fibrillar component of the extracellular matrix in the area of scaffold implantation, which was confirmed by fractal analysis. In the experimental group $\mathrm{N} 2$, the value of the fractal distribution (on a scale from 0 to 2 units) was $1.77(1.73-1.83)$ units, which was $2.91 \%$ more $(p=0.042)$ than in the comparison group N1 of 1.72 (1.711.77 ) units. Additionally, the value of the lacunarity index in the experimental group N2 was $0.285(0.200-0.300)$ units, which was $5 \%$ less $(p=0.281)$ than in the comparison group N1 of $0.30(0.270-0.327)$ units. These changes in the fibrillar component of the extracellular matrix in the area of implantation of the scaffold with D-asparagine may indicate a complication of the fractal structure and a decrease in the degree of its disorganization, in relation to the comparison group [11]. 

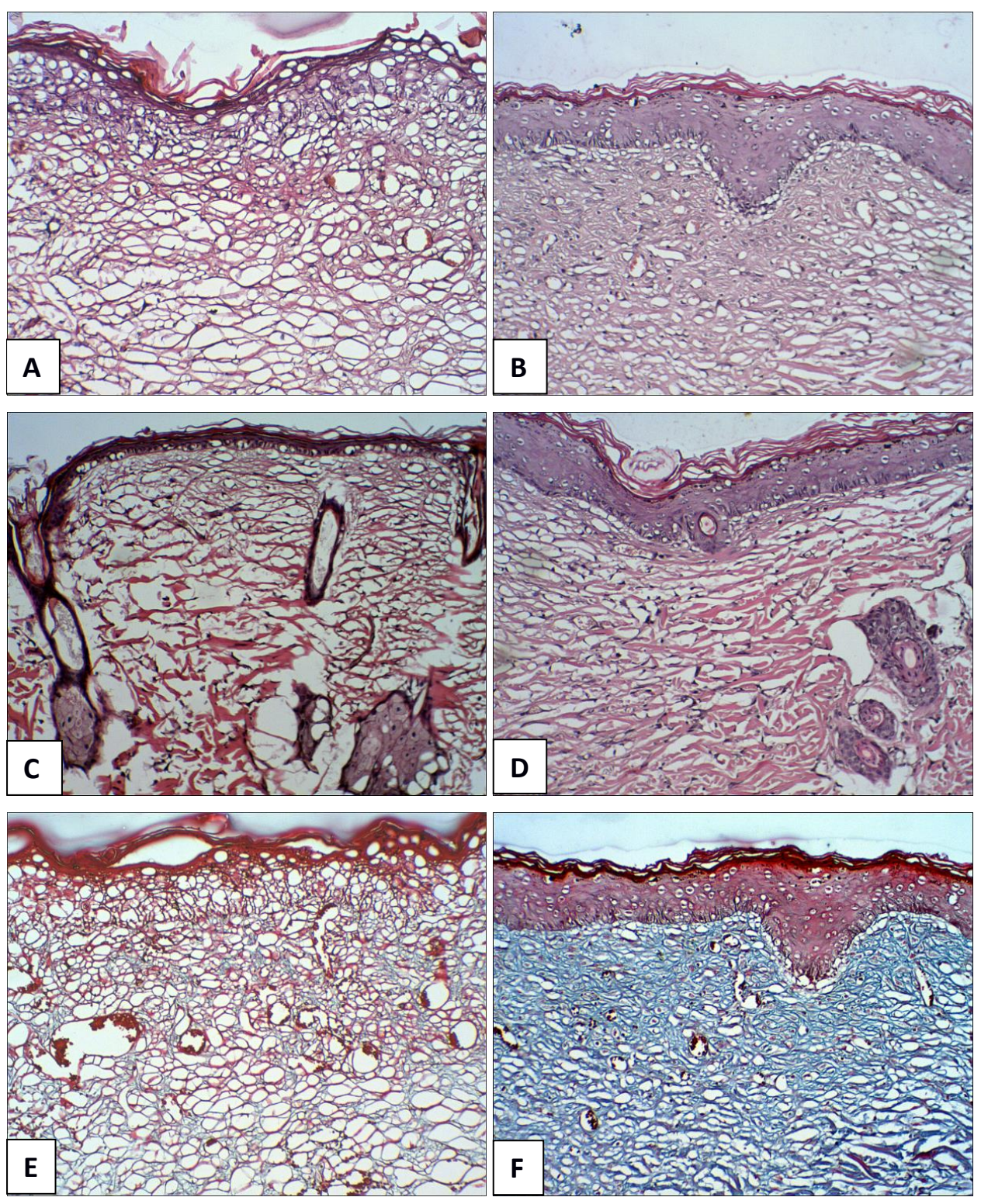

Fig. Biopolymer scaffold on the 30th day after implantation: A and C - comparison group N1; $\mathrm{B}$ and D - experimental group N2; hematoxylin-eosin staining, x200 magnification;

E - comparison group N1; F - experimental group N2, Mallory-Slinchenko staining, magnification x200
Conclusions. The study showed that the inclusion of D-asparagine in the composition of the scaffold, the main components of which were sodium alginate and gelatin, had a positive effect on its engraftment and remodeling. On day 30 after the scaffold implantation to close the area after necrectomy of burn wounds in rats, D-asparagine provided activation of the proliferative activity of cells, with differentiation of the epidermis. In addition, the study revealed that the proposed scaffold is a promising material for replacing the skin in burn wounds.

Experimental animal procedures. The study was performed in accordance with the provisions of the European Convention for the Protection of Vertebrate Animals used for Experimental or Other Scientific Purposes (Strasbourg, 1986; ed. Strasbourg, 2006) and in accordance with international legislation on the protection of animals used for scientific purposes (Directive 2010/63/EU). The maintenance and use of animals for experimental purposes was performed in accordance with the international rules «Guide for the Care and Use of Laboratory Animals - 8th edition, 2011». The study protocol was approved by the Local Ethical Committee.

Disclosures: The authors declare no conflict of interest.

\section{References}

1. Kogan S., Halsey J., Agag R. L. Biologics in Acute Burn Injury. Annals of Plastic Surgery. 2019;83(1):26-33. https://doi.org/10.1097/SAP.0000000000001915

2. Lo C. H., Chong E., Akbarzadeh S., Brown W. A., Cleland $\mathrm{H}$. A systematic review: Current trends and take rates of cultured epithelial autografts in the treatment of patients with burn injuries. Wound Repair and Regeneration. 2019;27(6):693-701. https://doi.org/10.1111/wrr.12748

3. Nielson C. B., Duethman N. C., Howard J. M., Moncure M., Wood J. G. Burns: Pathophysiology of Systemic Complications and Current Management. Journal Burn Care \& Research. 2017;38(1):e469-e481. https://doi.org/10.1097/BCR.0000000000000355

4. Afjoul H., Shamloo A., Kamali A. Freeze-gelled alginate/ gelatin scaffolds for wound healing applications: An in vitro, in vivo study. Materials Science and Engineering. 2020;113:110957.

https://doi.org/10.1016/j.msec.2020.110957

5. Jin S., Xia X., Huang J., Yuan C., Zuo Y. [et al.] Recent Advances in PLGA-based Biomaterials for Bone Tissue
Regeneration. Acta Biomaterialia. 2021:S1742-7061(21) 00224-5. https://doi.org/10.1016/j.actbio.2021.03.067

6. Sergeeva Yu. A., Trofimenko A. I., Fedorenko T. V., Gilevich I. V., Kolomiyceva E. A., Kade A. H. Influence of D-asparagine on the proliferative activity of human dermal fibroblasts. Medical News of North Caucasus. 2020;15(3):360-363.

https://doi.org/10.14300/mnnc.2020.15085

7. Genchi G. An overview on D-amino acids. Amino Acids. 2017;49(9):1521-1533.

https://doi.org/10.1007/s00726-017-2459-5

8. Du S., Wang Y., Alatrash N., Weatherly C. A., Roy D. [et al.] Altered profiles and metabolism of I-and d-amino acids in cultured human breast cancer cells vs non-tumorigenic human breast epithelial cells. Journal of Pharmaceutical and Biomedical Analysis. 2019;164:421-429. https://doi.org/10.1016/j.jpba.2018.10.047

9. Cai E. Z., Ang C. H., Raju A., Tan K. B., Hing E. C. H. [et al.] Creation of consistent burn wounds: a rat model. Archives of Plastic Surgery. 2014;41(4):317-324. https://doi.org/10.5999/aps.2014.41.4.317 
10. Lopes R., Betrouni N. Fractal and multifractal analysis: a review. Medical Image Analysis. 2009;13(4):634-49. https://doi.org/10.1016/j.media.2009.05.003

11. Frisch K. E., Duenwald-Kuehl S. E., Kobayashi H., Chamberlain C. S., Lakes R. S. [et al.] Quantification of collagen organization using fractal dimensions and Fourier transforms. Acta histochemica. 2012:114(2):140-144. https://doi.org/10.1016/j.acthis.2011.03.010

\title{
About autors:
}

Kade Azamat Khalidovich, MD, DMSc, Professor, Head of the Department of general and clinical pathological physiology; tel.: +79882420477; e-mail: akh_kade@mail.ru; https://orcid.org/0000-0002-0694-9984

Trofimenko Artem Ivanovich, DMSc, Assistant of the Department, researcher of the Scientific and Organizational Department; tel.: +79182531100; e-mail: artemtrofimenko@mail.ru; https://orcid.org/0000-0001-7140-0739

Bogdanov Sergey Borisovich, MD, DMSc, Professor of the Department of orthopedics, traumatology and MFS,

Head of the Burn Department; tel.: +79186502857; e-mail: bogdanovsb@mail.ru; https://orcid.org/0000-0001-9573-4776

Galushko Yulia Valentinovna, student; tel.: +79183005180; e-mail: galushko_yuliya22@mail.ru

Zench Sabina Muratovna, student; tel.: +79384959430; e-mail: zench_sabina87@mail.ru

(C) Group of authors, 2021

UDC 616-008.9-092.4+615.03+616.8

DOI - https://doi.org/10.14300/mnnc.2021.16043

ISSN - 2073-8137

\section{THE ROLE OF DYSMETABOLIC MECHANISMS IN THE DEVELOPMENT OF NEURODEGENERATIVE PROCESSES IN AN EXPERIMENTAL METABOLIC-COGNITIVE SYNDROME MODEL}

Petrenko V. I. 1, Shevandova A. A. ', Kubyshkin A. V. 1, Fomochkina I. I. 1, Shramko Yu. I. ${ }^{1}$, Makalish T. P. ${ }^{1}$, Ogay Yu. A. ${ }^{2}$, Khusainov D. R. ${ }^{3}$

${ }^{1}$ Medical Academy named after S. I. Georgievsky of V. I. Vernadsky

Crimean Federal University, Simferopol, Russian Federation

2 All-Russian National Scientific Research Institute of Viniculture and Winemaking, Yalta, Russian Federation

${ }^{3}$ Tauride Academy of V. I. Vernadsky Crimean Federal University, Simferopol, Russian Federation

\section{ИЗУЧЕНИЕ РОАИ АИСМЕТАБОАИЧЕСКИХ МЕХАНИЗМОВ В РАЗВИТИИ НЕЙРОАЕГЕНЕРАТИВНЫХ ПРОЦЕССОВ ПРИ ЭКСПЕРИМЕНТААЬНОМ МОАЕАИРОВАНИИ МЕТАБОАИКО-КОГНИТИВНОГО СИНАРОМА}

\author{
В. И. Петренко ${ }^{1}$, А. А. ШеванАова ${ }^{1}$, А. В. Кубышкин ${ }^{1}$, И. И. Фомочкина ${ }^{1}$, \\ Ю. И. Шрамко ', Т. П. Макалиш ${ }^{1}$, Ю. А. Огай ${ }^{2}$, А. Р. Хусаинов ${ }^{3}$
${ }^{1}$ МеАицинская акалемия им. С. И. Георгиевского Крымского фелерального университета им. В. И. ВернаАского, Симферополь, Российская ФеАерация
2 Всероссийский национальный научно-исслеАовательский институт винограАарства и виноАелия, ЯАта, Российская ФеАерация
${ }^{3}$ Таврическая акаАемия Крымского фелерального университета им. В. И. Верналского, Симферополь, Российская ФеАерация

This article describes the role of dysmetabolic mechanisms in the development of neurodegenerative processes in an experimental animal model of metabolic-cognitive syndrome. Cognitive decline and neurodegenerative changes in experimental animals were revealed in the form of decreased cortical thickness in the temporal and parietal lobes of the brain. Administration of polyphenol preparations prevented morphological and functional changes in animals. Neuroprotection in individuals with metabolic syndrome can be individualized using drugs with different polyphenol compositions.

Keywords: neurodegeneration, metabolic syndrome, cognitive impairment, polyphenols

Описаны результаты изучения роли дисметаболических механизмов в развитии нейродегенеративных процессов при экспериментальном метаболико-когнитивном синдроме. Выявлены когнитивное снижение и нейродегенеративные изменения у экспериментальных животных в виде уменьшения толщины коры в височно-теменных долях головного мозга. При коррекции полифенольными препаратами наблюдалось нивелирование морфофункциональных из- 